\title{
NEUROSECRETORY CELLS OF THIRD-INSTAR LARVAE OF ANASTREPHA OBLIQUA MACQUART (DIPTERA, TEPHRITIDAE)
}

\author{
Isabel C. Boleli ${ }^{1}$ \\ Zilá L. Paulino-Simões ${ }^{1}$ \\ † M. Madalena da Costa Teles ${ }^{1}$
}

\begin{abstract}
Neurosecretory cells of the nervous system of third-instar larvae of Anastrepha obliqua Macquart, 1835 were located and deseribed histomorphologically. Six groups of neurosecretory cells were identified in the brain and one group in the ventral ganglion. The groups differed in position, cell size and staining characteristics. Four of these groups appear to be active throughout the third instar and three, from the prepupal period.

KEY WORDS. Anastrepha obliqua, fruit fly, neurosecretory cells
\end{abstract}

Neurosecretory cells are classically defined as neurons that synthetize peptides (neurohormones), which are released into the bloodstream and act at a distance (SCHARRER 1977; KRIEgER 1983; LAFONT 1991). Today, however, it is also know that the same neuron can produce peptides as well as monoamines, and that a neurosecretion may also act as neurotransmitters and neuromodulators (HöKFElT et al. 1980; ORCHARD 1982; RAABE 1989; ORCHARD et al. 1992).

Neurosecretory system, in essence, takes information from outside and inside the animal, screens, processes, and integrates everything, and then directs the appropriate action or activity (GRIER 1984). Specifically during the larval stage, it regulates the initiation of the moulting process and later growth by controlling the activities of endocrine glands (NORMAN 1965; CAZAL et al. 1971; BLIGHT \& WENHAN 1976; GiLberT et al. 1980; GRANGER \& BOLLENBACHER 1981; Agui et al. 1980; SEDLAK 1985; HenRICH et al. 1987). Futhermore, at the end of the larval stage, it induces differentiation of adult primordia (LOCKE 1981), and metamorphosis events (ZDAREK 1980).

Neurosecretory cells are present in the entire nervous system (RAABE 1989; ORCHARD \& LOUGHTON 1985), and analogous groups have been detected in several insects.

A survey of the literature showed the absence of studies on the neurosecretory cells of $A$. obliqua Macquart, 1835 . This fruit fly is a pest, whose larval stage causes enormous damage to the fruit-growing industry, and studies of its neurosecretory system are essential for the understanding of its physiology of development. So this paper describes histomorphologically the PF-positive neurosecretory cells of third-instar $A$. obliqua larvae.

1) Departamento de Biologia. Faculdade de Filosofia. Ciências e Lutras de Ribeirão Preto, Universidade de São Paulo, Av. Bandeirantes 3900, 14(40-901 Ribcirão Preto, São Paulo, Brasil. 


\section{MATERIAL AND METHODS}

A. obliqua larvae were obtained in the laboratory from wild adults infesting Spondias purpurea Linnaeus (ceriguela) fruits collected and maintained according to the methods used by Bressan (1981), Polloni (1981) and Silva et al. (1985).

Developing larvae were maintained on nutritionally efficient diet (diet-2) (SIMÕES-JORGE 1987), which contained a mixture of brewer's yeast, sucrose, starch, agar, propionic acid, nipagin and distilled water. Larvae were kept in a wood chamber with a thermostat maintaining at temperature of $25^{\circ} \mathrm{C}$ and with approximately $75 \%$ relative humidity. Larval stages were recognized on the basis of morphology and colour of buccal hooks according to TELES DA SILVA (1978).

On each day of the third larval instar, except the third and 11 th days, ten larvae were dissected and the complex brain-ventral ganglion-Weismann gland set was fixed in Bouin's for 24 hours. After standard embedding in paraffin, longitudinal and transversal serial sections were cut and stained by the paraldehyde-fucsin technique of EWEN (1962) for the neurosecretory products of insects. All larvae, which were used in the present work, had passed to third instar on the sixth post-hatching day. Furthermore, the larvae of the same age used in the present study were those which presented similar weight and length.

Different groups of neurosecretory cells in the third instar were determined and phases were described on the basis of the cytoplasmic staining of these cells. Neurosecretory cells belonging to the various widest and shortest cellular and nuclear diameters were measured.

\section{RESULTS}

Seven groups of neurosecretory cells were identified in the nervous system of third-instar $A$. obliqua larvae. Of these, six were found in each brain hemisphere and one in the ventral ganglion (Fig. 1), as described below:

GROUP 1 - is formed by two cells located in the dorso-anterior region of the brain close to the junction of the two brain hemispheres in the pars intercerebralis (Fig. 1 a-d'). These cells have a maximum cell size of $4 \times 5 \mu \mathrm{m}$ and a maximum nuclear size of $2 \times 3 \mu \mathrm{m}$ (Fig. 2).

Group 2. Consists of one cell located in the ventro-anterior region of the brain hemispheres but in the same direction as that of group 1 (Fig. 1 a-a'). The maximum cell and nuclear diameters of this cell are $4 \times 6 \mu \mathrm{m}$ and $2 \times 3 \mu \mathrm{m}$, respectively. Vacuoles are normally observed in these cells (Fig. 3).

Group 3. Has nine to fourteen cells located in the dorso-anterior region of the brain hemisphers (Fig. 1 a-a'). The maximum approximate cell diameters of these cells are $5 \times 7 \mu \mathrm{m}$, and the nuclear diameters, $2 \times 3 \mu \mathrm{m}$. These cells may present vacuoles (Fig. 4).

Group 4. Has four small cells more or less oval in shape with maximum cellular and nuclear sizes of about $3 \times 4 \mu \mathrm{m}$ and $2 \times 3 \mu \mathrm{m}$, respectively. This group is detected in the dorso-lateral region of the hrain hemispheres (Figs I b-b'; 5). 


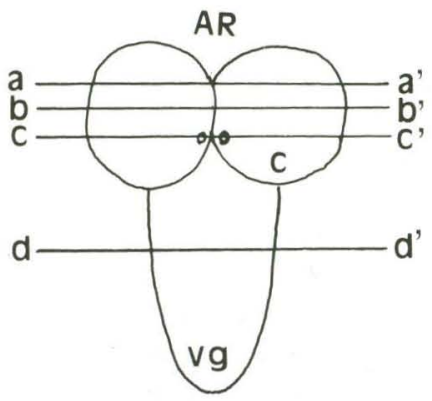

\section{A}

\section{PR}
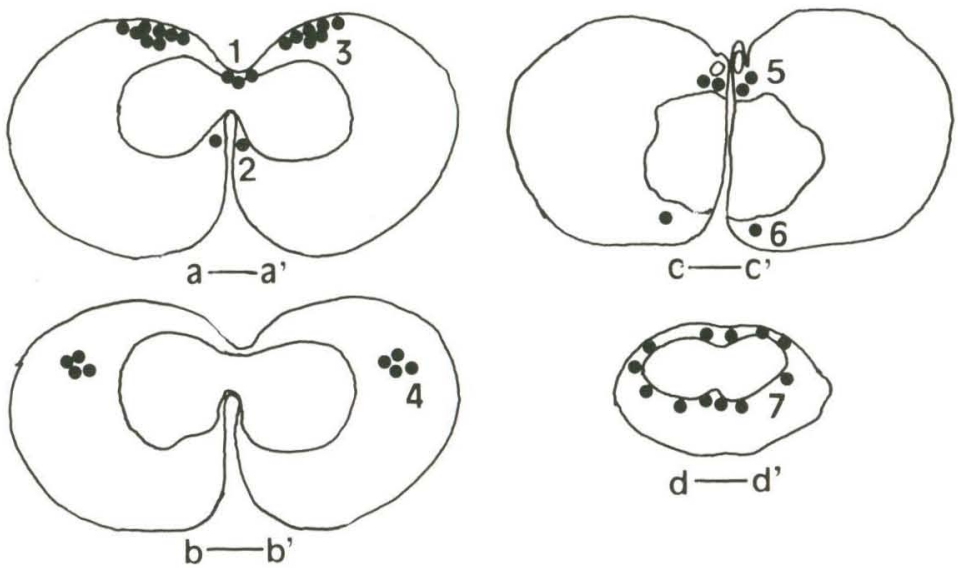

B

Fig. 1. (A) Schematic dorsal view of the nervous system of third-instar Anastrepha obliqua larvae showing the position of the transversal sections $a-a^{*}, b_{-}-b^{\prime}, c-c^{\prime}$ and $d-d$ '. (B) Diagrams showing the location of neurosecretory cell groups (black dots) in the nervous system of third-instar $A$. obliqua larvas, according to the sectioning planes. $s$ : brain; vg: ventral ganglion: 1-7: neurosecretory cell groups: AR, PR: anterior and posterior regions.

Group 5. Consists of two cells located close to the tracheal opening in the dorso-posterior region of the hrain (Fig. $\left.1 \mathrm{c}-\mathrm{c}^{\prime}\right)$. Their approximate maximum cellular and nuclear sizes are $3 \times 5 \mu \mathrm{m}$ and $2 \times 3 \mu \mathrm{m}$, respectively (Fig. 6).

GROUP 6. Is formed hy one cell located in the ventro-posterior region of the brain (Fig. $1 \mathrm{c}-\mathrm{c}$ ') which measures a maximum of $3 \times 5 \mu \mathrm{m}$ and has a nucleus of $2 \times 3 \mu \mathrm{m}$ (Fig. 7).

Group 7. Has various cells distributed along the ventral ganglion and always around the medullary region of the latter (Fig. $1 \mathrm{~d}$-d'). These cells reach cell diameters of $3 \times 4 \mu \mathrm{m}$ and nuclear diameters of $1 \times 2 \mu \mathrm{m}$ (Fig. 8).

The neurosecretory cells detected in the hrain hemispheres (group 1-6) are all unipolar, whereas those located in the ventral ganglion (group 7) are bipolar (Figs 2-8). 


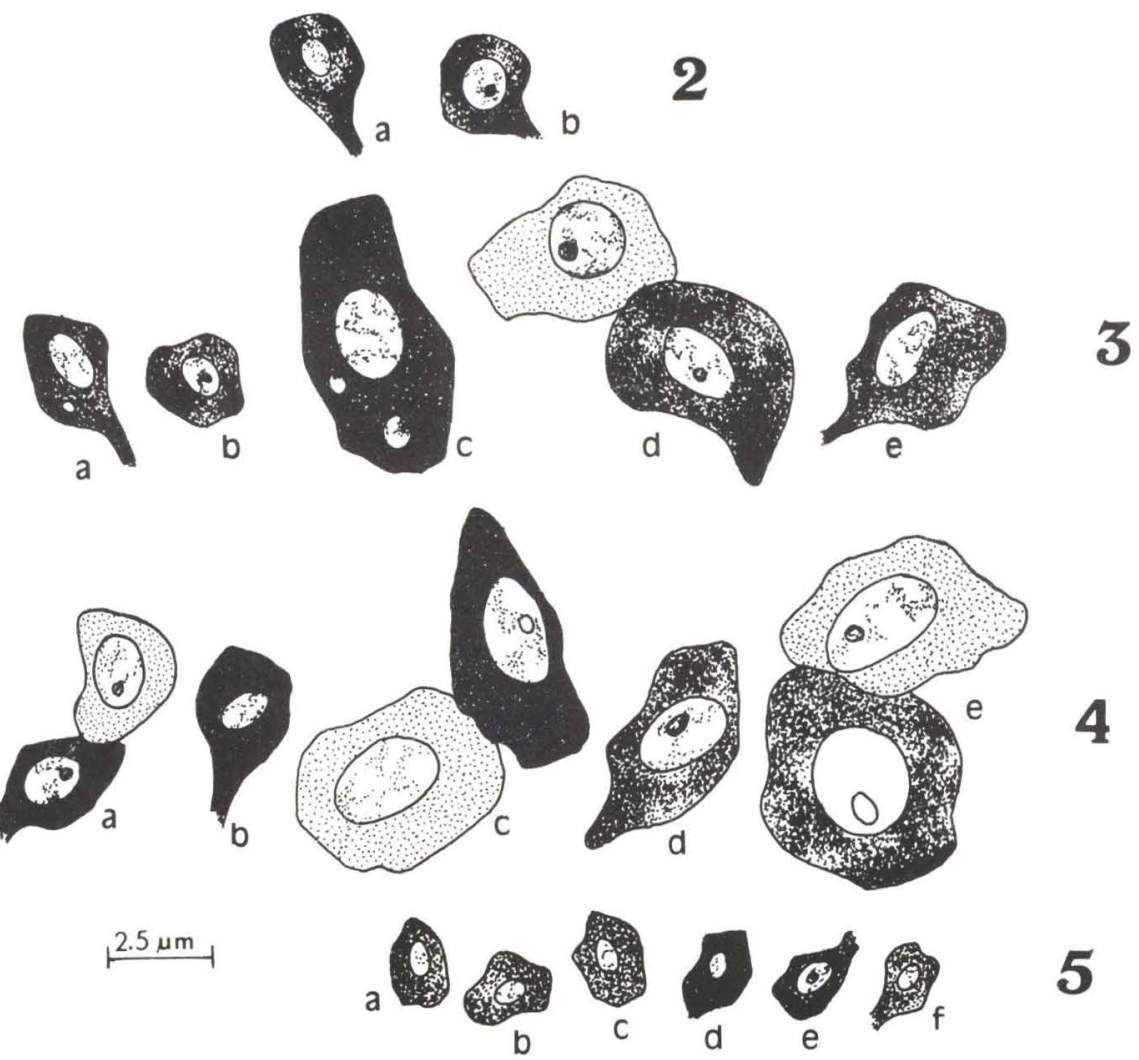

Figs 2-5. Schematic light-camera drawing of groups 1, 2, 3, 4 and 5 neurosecretory cells of third-instar Anastrepha obliqua larvae, respectively, aged one (a), two (b), seven (c). eleven (d) fourteen (e), seventeen (1) and twenty-one (g) days of life, showing variations in the amount of neurosecretory present in the cytoplasm (black dots) and increasing cell size with larval age.

During the first days of the third larval instar, group 2 and 3 cells underwent a considerably marked increase in volume (Figs 3 and 4). The same was observed for groups 1 and 4 (Figs 2 and 5). Groups 5, 6 and 7 were only identified during the prepupal phase.

The neurosecretory cells of groups 1-4 showed changing cytoplasm staining during the course of the instar (Tab. I, Figs 2, 3, 4 and 5). These variations were represented by the following symbols:

$\mathbf{0}$ - the cytoplasm stains green.

+- the cytoplasm stains light gray.

++- the cytoplasm stains purple but staining is not uniform, i.e., there are regions with deeply stained granules and regions with only a few or no stained granules. At times, stained material can be observed in the axon region.

+++- the cytoplasm is fully stained purple and is completely filled with 

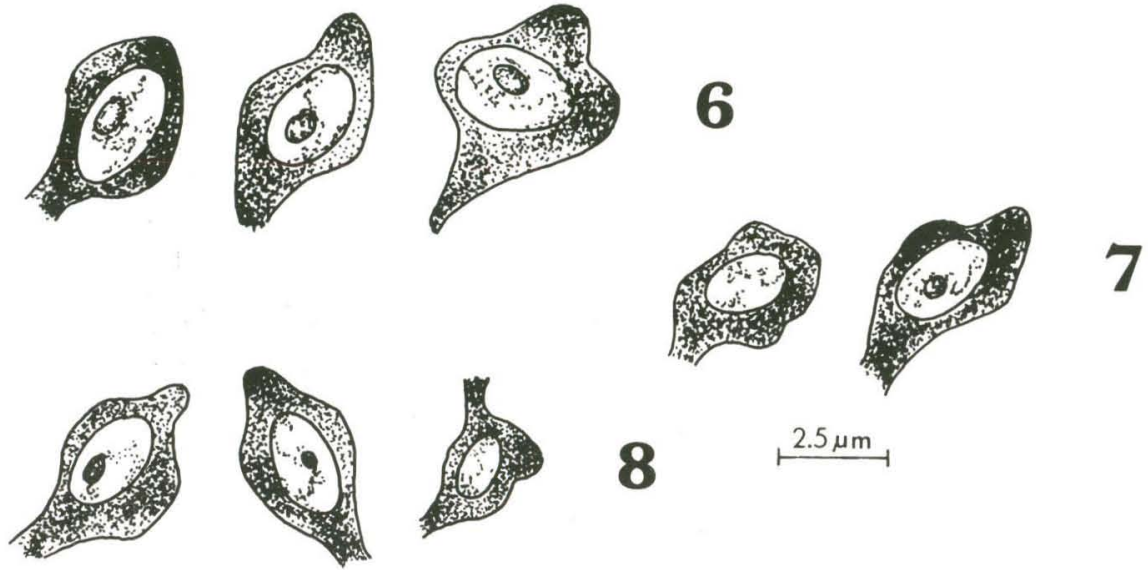

Figs 6-8. Schematic light-camera drawing of group 5,6 and 7 neurosecretory cells of white Anastrepha obliqua prepupae.

Table I. Cytoplasm staining in neurosecretory cells of groups 1, 2, 4, 5, 6 and 7 from third-instar Anastrepha obliqua larvae and prepupal phase (PP).

\begin{tabular}{lllllll}
\hline A & 1 & 2 & 4 & 5 & 6 & 7 \\
\hline 01 & ++ & ++ & + & 0 & 0 & 0 \\
02 & ++ & ++ & ++ & 0 & 0 & 0 \\
04 & +++ & +++ & +++ & 0 & 0 & 0 \\
05 & + & + & + & 0 & 0 & 0 \\
06 & 0 & ++ & 0 & 0 & 0 & 0 \\
07 & + & ++ & ++ & 0 & 0 & 0 \\
08 & 0 & +++ & 0 & 0 & 0 & 0 \\
09 & ++ & ++ & 0 & 0 & 0 & 0 \\
10 & + & +++ & + & 0 & 0 & 0 \\
11 & + & ++ & + & 0 & 0 & 0 \\
12 & ++ & ++ & ++ & 0 & 0 & 0 \\
14 & 0 & +++ & ++ & 0 & 0 & 0 \\
16 & + & +++ & + & 0 & 0 & 0 \\
17 & ++ & +++ & ++ & 0 & 0 & 0 \\
19 & 0 & ++ & ++ & 0 & 0 & 0 \\
20 & ++ & ++ & ++ & 0 & 0 & 0 \\
21 & 0 & +++ & +++ & 0 & 0 & 0 \\
PP & ++ & +++ & ++ & + & ++ & ++ \\
\hline
\end{tabular}

A: Third-instar days.

0: Green-staining cytoplasm: + : light gray cytoplasm; ++ : purple cytoplasm with instained regions: +++ : uniformly purple-stained cytoplasm. 
Table II. Number of group 3 neurosecretory cells in each brain hemisphere (B) of the third-instar Anastrepha obliqua larvae of identical and different ages (A), and variations in cytoplasm staining in the cells of each hemisphere (C).

\begin{tabular}{|c|c|c|c|c|c|c|c|c|}
\hline A & B & & & & C & & & \\
\hline 01 & 09-09 & & $9++$ & & - & & $9++$ & \\
\hline 02 & $10-10$ & $5+$ & $5++$ & & . & $5+$ & $3++$ & \\
\hline 04 & $10-10$ & $2+$ & $5++$ & $3+++$ & - & $4+$ & $4++$ & $2+++$ \\
\hline 05 & $12-10$ & $6+$ & $6++$ & & - & $6+$ & $4++$ & \\
\hline 06 & $11-10$ & $9+$ & $2++$ & & - & $9+$ & $1++$ & \\
\hline 07 & $11-10$ & $6+$ & $4++$ & $3+++$ & & $5+$ & $3++$ & $2+++$ \\
\hline \multirow[t]{2}{*}{08} & $11-10$ & $7+$ & $3++$ & $1+++$ & & $6+$ & $4++$ & \\
\hline & $10-10$ & $6+$ & $4++$ & & - & $8+$ & $2++$ & \\
\hline 09 & $11-11$ & $6+$ & $5++$ & & & $6+$ & $5++$ & \\
\hline \multirow[t]{2}{*}{10} & $11-11$ & $8+$ & $3++$ & & - & $9+$ & $2++$ & i \\
\hline & $11-10$ & $8+$ & & $3+++$ & - & $7+$ & $2++$ & $1+++$ \\
\hline \multirow[t]{2}{*}{11} & $11-10$ & $6+$ & $5++$ & & - & $5+$ & $5++$ & \\
\hline & $11-10$ & $7+$ & $3++$ & $1+++$ & - & $6+$ & $2++$ & $2+++$ \\
\hline 12 & $12-12$ & $7+$ & $2++$ & $3+++$ & - & $6+$ & $2++$ & $4+++$ \\
\hline 14 & $11-10$ & $8+$ & & $3+++$ & - & $6+$ & & $4+++$ \\
\hline \multirow[t]{2}{*}{16} & $11-10$ & $6+$ & $2++$ & $3+++$ & - & $6+$ & & $4+++$ \\
\hline & $12-11$ & $6+$ & $3++$ & $3+++$ & - & $6+$ & $3++$ & $2+++$ \\
\hline \multirow[t]{2}{*}{17} & $10-10$ & $6+$ & $3++$ & & - & $6+$ & $3++$ & $1+++$ \\
\hline & 14-11 & $7+$ & $5++$ & $3+++$ & - & $8+$ & $3++$ & \\
\hline 18 & $13-12$ & $8+$ & $4++$ & $1+++$ & - & $8+$ & $3++$ & $1+++$ \\
\hline 20 & $14-12$ & $9+$ & $5++$ & & - & $5+$ & $6++$ & $1+++$ \\
\hline 21 & $11-10$ & $6+$ & $4++$ & $1+++$ & - & $5+$ & $6++$ & \\
\hline PP & $11-10$ & & $9++$ & $2+++$ & - & & $10++$ & \\
\hline
\end{tabular}

+ : light gray eytoplasm; ++ : purple eytoplasm with instained regions; +++ : uniformly purplestained cytoplasm.

densely accumulated stained granules. At times the nucleus is poorly visible due to the accumulation of surrounding stained material.

The difference in cytoplasm staining as also detected between group 3 cells in the same hemisphere and in opposite hemispheres of the same individual or of distinct individuals (Tab. II):

The cytoplasm of the neurosecretory cells of groups 5, 6 and 7 was stained light purple $(++)$.

Purple-stained material was detected in the cytoplasm of prothoracic gland cells and in the corpora cardiaca region of white prepupae.

\section{DISCUSSION}

The groups of PF-positive neurosecretory cells of the nervous system of $A$. obliqua larvae show correspondence in the location, staining and number of cells with those of Lucilia caesar Linnaeus, 1758, Sarcophaga bullata Parker, 1916 
(Sarcophagidae) and Calliphora erythrocephala Meigen, 1830 (Calliphoridae) larvae (all of them Diptera Cyclorrhapha) studied by FRASER (1959 a,b), DOGRA \& TANDAN (1965) and VERNIER \& VERNIER (1969), respectively.

Groups 1 and 2 of the neurosecretory cells of $A$. obliqua are equivalent to group 1 and 2 of $L$. caesar and C. erythrocephala, and group 1 and 3 of Sarcophaga ruficornis (Fabricius, 1794). However, it exists in C. erythrocephala an additional cell (three rather than two).

Group 3 of $A$. obliqua corresponds to group 2 of $S$. ruficornis and group 3 of $C$. erythrocephala, but these species have a distinct number of cells. This group presents 20-22 cells in $S$. ruficornis, 12 in $C$. erythrocephala and 18-26 in $A$. obliqua. As in $S$. ruficornis, in $A$. obliqua this group does not present correspondence between cell number and variation in cytoplasm staining, between opposite brain hemispheres, or between larvae of the same age. These variations seem to indicate that groups 3 (with 4 cells) and 4 (with 7 cells) of L. caesar correspond to group 3 of $A$. obliqua. Thus, the difference in number of group 3 cells among these four species may be due to variations in the amount of neurosecretion.

Group 4 of $A$. obliqua is equivalent to group 5 of $L$. caesar, group 4 of $S$. ruficornis and group 6 of $C$. erythocephala. However, in $C$. erythrocephala the number of cells in each hemisphere is smaller than in the other species, i.e., there are three rather that four cells.

Group 5 of $A$. obliqua represents group 6 of $L$. caesar and group 5 of $C$. erythrocephala. These species present equal number of cell, i.e., two cells. This group was not observed in $S$. ruficornis.

Group 6 of $A$. obliqua was observed only in $C$. erythrocephala. In this species, group 6 has three cells in each hemisphere, whereas in $A$. obliqua it only has one.

Group 7 of $A$. obliqua was detected only in L. ceasar.

The existence of relationship between the PF-positive cells of these species belonging to four different families colaborates the assumption that these neurosecretory cells groups were conserved in the Cyclorrhapha evolutive process.

Although the neurosecretory cells of groups 1,2, 3 and 4 of $A$. obliqua presented variation in the amount of neurosecretion throughout the stage and even absence of neurosecretion (groups 1 and 4), our data provide no explanation for the origin of these changes, i.e., whether they were due to a process of synthesis or of secretion. However, the continuous presence of neurosecretion in group 2 and 3 during the third instar indicates that these groups may be related to the larval-pupal moult or metamorphosis events.

The presence of stained substances observed inside the cells of the prothoracic gland of $A$. obliqua during the prepupal phase was also observed in C. erythrocephala by VERNIER \& VERNIER (1969) during the post-feeding period. SLOPER (1957, 1958 apud FrASER 1959a) and later FrIEDEL et al. (1980) determined that this substance is the amino acid cystine.

Our data show that the NSC of groups 2 and 3 seem to reach their maximum size on the 7 th day of third instar. This suggests the possibility that larval system 
reach maximum growth during the first days of third instar, a fact that may be advantageous or even necessary for a larva who has the important role of assuring successful pupal development hy the accumulation of large amounts of nutritional reserves.

ACKNOWLEDGMENTS. The authors are grateful to "Coordenadoria de Aperfiçoamento de Pessoal de Nivel Superior" (CAPES) for financial support, and to COPERSUCAR for permitting the use of their orchard for fruit collection.

\section{REFERENCES}

Agui, N.; W.E. Bollenbacher; N.A. Granger \& L.I. Gilbert. 1980. Corpus allatum is release site for insect prothoracicotropic hormone. Nature, London, 285: $669-70$.

Blight, M.M. \& M.J. Wenham. 1976. Juvenile hormone activity in larvae and adult females of the locust, Schistocerca gregaria. J. Insect Physiol. 22: 141-45.

BREsSAN, S. 1981. Aspectos biológicos de algumas espécies do gênero Anastrepha Schiner 1868 (Diptera - Tephritidae) na região de Ribeirão Preto. Dissertação de Mestrado, não publicada, Universidade de São Paulo, Ribeirão Preto, 250p.

Cazal, M.; L. Joly \& A. PORTE. 1971. Étude ultrastructurale des corpora cardiaca et de quelques formations annexes chez Locusta migratoria L.. Z . Zellforsch. mikrosk. Anat. 114: 61-72.

Dogra, G.S. \& B.K. TANDAN. 1965. Ontogenetic fate of the neurosecretory cells in the larval brain of Sarcophaga ruficornis (Fabricius, 1794) (Diptera Cyclorrhapha). Experientia 21: 216-18.

EWEN; A.B. 1962. An improved aldehyde-fuchsin staining technique for neurosecretory products in insects. Trans. Aer. mikrosk. Soc. 81: 94-6.

FRASER, A. 1959a. Neuroseretory in the brain of the larvae of the sheep blowfly, Lucilia caesar (Diptera). Q. J. microsc. Sci. 100 (3): 377-99.

1959b. Neurosecretory cells in the abdominal ganglia of larvae of Lucilia caesar. Q. J. microsc. Sci. 100 (3): 395-9.

Friedel, T.; B.G. LUOGHTON \& R.D. AndeAs. 1980. A neurosecretory protein from Locusta migratoria. Gen. comp. Endocr. 41: 487-98.

Gilbert, L.I.; W.E. Bollenbacher; W. Goodman; S.L. Smith; N. Agui; N. Granger \& B.J. SEDlAK. 1980. Hormones controlling insect metamorphosis. Recent Prog. Hormone Res. 36: 401-49.

Granger, N.A. \& W.E. Bollenbacher. 1981. Hormonal control of insect metamorphosis, 105-137p. In: L.I. GILBERT \& E. Friedel (Eds.). Metamorphosis - a problem in development biology. New York and London, Plenum Press, 2nd ed.

Grier, J.W. 1984. Biology of Animal Behavior. Times Mirror/Morby College Publishing, XIX +693p. 
Henrich, V.C.; R.L. Tucker; G. Maroni \& L.I. Gilbert. 1987. The ecdysoneless (eed 1 ts) mutation disrupts ecdysteroid synthesis autonomously in the ring gland of Drosophila melanogaster. Devl. Biol. 120: 50-5.

KökfElt, T.; O. Johanson; A. LJungdahl; J.M. Lundberg \& M. SchultzBERG. 1980. Peptidergic neurons. Nature 284: 515-21.

KRIEGER, D.T. 1983. Brain peptides: What, where, and why? Science 222: 975-85.

LAFONT, R. 1991. Endocrinology or "hormone" seeking functions. Insect Biochem. 21 (7): 697-721.

LOCKE, M. 1981. Cell during insect metamorphosis, 73-103p. In: L.I. GILBERT \& E. FRIEDEN (Eds). Metamorphosis - a problem in development biology. New York and London, Plenum Press, 2nd. Ed.

Normann, T.C. 1965. The neurosecretory system of the adult Calliphora erythrocephala. 1. The fine structure of the corpus cardiacum with some observations on adjacent organs. Z. Zellforsch. 67: 461-501.

ORCHARD, I. 1982. Octopamin in insects: neurotransmitter, neurohormone, and neuromodulator. Can. J. Zool. 60: 659-69.

Orchard, I. \& B.G. Loughton. 1985. Neurosecretion, 61-107p. In: G.A. Kerkut \& L.I. Gilbert. Comprehensive Insect Physiology Biochemistry and Pharmacology. Oxford, Pergamon Press.

ORChARD, I; A.B. LANGE \& B.B. BRown. 1992. Tyrosine hydroxylase-like immunoreactivity in the ventral nerve cord of the locust (Locusta migratoria), including neurones innervating the salivary glands. J. Insect Physiol. 38 (1): 19-27.

Polloni, Y.J. 1981. Aspectos do comportamento reprodutivo de algumas espécies de moscas-das-frutas do gênero Anastrepha Schiner, 1868 (Diptera: Tephritidae) em laboratório. Dissertação de Mestrado, não publicada, Universidade de São Paulo, Ribeirão Preto, 108p.

RAABE, M. 1989. Recent Development in Insect Neurohormones. New York and London, Plenum Press, XXII + 503p.

Scharrer, B. 1977. Peptides in neurobiology historical introduction, p.1-7. In: H. Gainer (Ed.). Peptides in Neurobiology. New York, Plenum Press.

SEDlak, B.J. 1985. Structure of endocrine glands, p.25-60. In: J. KeRKUT \& L.I. Gilbert Comprehensive Insect Physiology - Biochemistry and Pharmacology. Oxford, Pergaman Press, vol. 7., Oxford.

Silva, M.T. Da; Y.J. Polloni \& S. Bressan. 1985. Mating behavior of some fruit flies of the genus Anctstrepha Schiner, 1968 (Diptera - Tephritidae) in the laboratory. Revta. bras. Ent. 29 (1): 155-64.

Simōes-Jorge, M.H. 1987. Estudos do desenvolvimento pós-embrionário de moscas-das-frutas do gênero Anastrepha Schiner, 1868 (Diptera Tephritidae). Dissertação de Mestrado, não publicada, Universidade de São Paulo, Ribeirão Preto, 180p.

Teles Da Silva, M.M. 1978. Algumas espécies de mosica-da-fruta do gênero Anastrepha (Diptera - Tephritidae). III Congresso Latini-Americano de 
Entomologia, Ilhéus, Bahia, 30p.

VERNIER, J.M. \& C. Vernier. 1969. Evolution des cellules neurosécrétrices protocérébrales et stimulation fonctionnelle de 1 anneau de Weismann par le cerveau chez Calliphora erythrocephala Meig. (Diptera - Cyclorrhapha). C. R. Acad. Sci., Paris, 268 (D): 2922-2925.

ZDAREK, J. 1980. Neurohormonal factors involved in the control factors pupariation, p.154-58. In: T.A. MILlER (Ed.) Neurohormonal Techniques in Insects. New York, Springer.

Recebido em 23.XI.1993; aceito em 11.X.1994 